\title{
Kinetic modelling of the electrochemical mineralization of organic pollutants for wastewater treatment
}

\author{
Agnieszka Kapałka · György Fóti · Christos Comninellis
}

Received: 11 May 2007 / Revised: 28 June 2007 / Accepted: 2 July 2007 / Published online: 6 September 2007

(C) Springer Science+Business Media B.V. 2007

\begin{abstract}
The electrochemical mineralization of organic pollutants is a new technology for treatment of dilute wastewater $\left(\mathrm{COD}<5 \mathrm{~g} \mathrm{~L}^{-1}\right)$. In this method, use of the electrical energy can produce complete oxidation of pollutants on high oxidation power anodes. An ideal anode for this type of treatment is a boron-doped diamond electrode (BDD) characterized by a high reactivity towards oxidation of organics. In the present work kinetic aspects of organic mineralization is discussed. The proposed theoretical kinetic model on boron-doped diamond anodes is in excellent agreement with experimental results. In addition economic aspects of electrochemical organic mineralization are reported.
\end{abstract}

Keywords Boron-doped diamond electrode .

Electrochemical mineralization - Organic pollutants .

Wastewater - Kinetic model

\section{Introduction}

Biological treatment of polluted water is the most economic process and is used for the elimination of "readily biodegradable" organic pollutants present in wastewater. The situation is completely different when the wastewater contains toxic and refractory (resistant to biological treatment) organic pollutants. One interesting possibility is to

\footnotetext{
A. Kapałka ( $\square)$ · G. Fóti · C. Comninellis ( $\square)$

Institute of Chemical Sciences and Engineering, Ecole

Polytechnique Fédérale de Lausanne (EPFL), 1015 Lausanne,

Switzerland

e-mail: agnieszka.cieciwa@epfl.ch

e-mail: christos.comninellis@epfl.ch
}

use a coupled process: partial oxidation-biological treatment. The goal is to decrease the toxicity and to increase the biodegradability of the wastewater before biological treatment. However, optimization of this coupled process is complex and usually complete mineralization of the organic pollutants is preferred. The mineralization of these organic pollutants can be achieved by complete oxidation using oxygen at high temperature or strong oxidants combined with UV radiation. Depending on the operating temperature, the type of used oxidant and the concentration of the pollutants in the wastewater, the mineralization can be classified into three main categories:

Incineration: Incineration takes place in the gas phase at high temperature $\left(820^{\circ} \mathrm{C}-1100^{\circ} \mathrm{C}\right)$. Its main characteristic is direct combustion with excess atmospheric oxygen. The technology is applied mainly for concentrated wastewater with chemical oxygen demand COD $>100 \mathrm{~g} \mathrm{~L}^{-1}$.

Wet air oxidation process (WAO): Wet air oxidation (WAO) can be defined as the oxidation of organic pollutants in an aqueous medium by means of oxygen from air at elevated temperature $\left(250-300{ }^{\circ} \mathrm{C}\right)$ and high pressure $\left(100-150\right.$ bar). Usually $\mathrm{Cu}^{2+}$ is used as a catalyst. The efficiency of the mineralization can be higher than $99 \%$ and the main by-products formed in the aqueous phase after the treatment are: acetone, methanol, ethanol, pyridine and methanesulfonic acid. The technology is attractive for treatment of wastewater with moderate concentration. The optimal chemical oxygen demand is in the domain: $50 \mathrm{~g} / \mathrm{L}>\mathrm{COD}>15 \mathrm{~g} \mathrm{~L}^{-1}$. Oxidation with strong oxidants: The oxidation of organic pollutants with strong oxidants $\left(\mathrm{H}_{2} \mathrm{O}_{2}, \mathrm{O}_{3}\right)$ takes place generally at room temperature. In order to increase the efficiency of mineralization, the oxidation takes place in 
the presence of catalyst and UV radiation. This technology is interesting for the treatment of dilute wastewater with $\mathrm{COD}<5 \mathrm{~g} \mathrm{~L}^{-1}$.

The electrochemical method for the mineralization of organic pollutants is a new technology and has attracted a great deal of attention. This technology is interesting for the treatment of dilute wastewater $\left(\mathrm{COD}<5 \mathrm{~g} \mathrm{~L}^{-1}\right)$ and is in competition with the process of chemical oxidation using strong oxidants. The main advantage of this technology is that chemicals are not used. In fact, only electrical energy is consumed for the mineralization of organic pollutants. Besides our contribution in this field [1-11], many other research groups are active in this promising technology [12-24].

The aim of the present work is to elucidate the basic principles of electrochemical mineralization (EM) using some model organic pollutants. The following points will be treated:

- Mechanism of the electrochemical oxygen transfer reaction

- Influence of anode material on the reactivity of electrolytic hydroxyl radicals

- Determination of the current efficiency in the electrochemical oxidation process

- Kinetic model of organic mineralization on BDD anodes

- Intermediates formed during the EM process using BDD

- Electrical energy consumption in the EM process

- Optimization of the EM process using BDD

\section{Mechanism of the electrochemical mineralization}

In electrochemical mineralization (EM) reactions oxygen is transferred from water to the organic pollutant using electrical energy. This is the so-called electrochemical oxygen transfer reaction (EOTR). A typical example of EOTR is the anodic EM of phenol (Eq. 1).

$$
\mathrm{C}_{6} \mathrm{H}_{5} \mathrm{OH}+11 \mathrm{H}_{2} \mathrm{O} \rightarrow 6 \mathrm{CO}_{2}+28 \mathrm{H}^{+}+28 \mathrm{e}^{-}
$$

In this reaction water is the source of oxygen atoms for the complete oxidation of phenol to $\mathrm{CO}_{2}$ at the anode of the electrolytic cell. The liberated protons in this reaction are discharged at the cathode to dihydrogen (Eq. 2).

$28 \mathrm{H}^{+}+28 \mathrm{e}^{-} \rightarrow 14 \mathrm{H}_{2}$

According to the generally accepted mechanism of the $\mathrm{EM}$, water is firstly discharged (at potentials above $1.23 \mathrm{~V} /$ SHE under standard conditions) at the anode active sites $\mathbf{M}$ producing adsorbed hydroxyl radicals (Eq. 3).
$\mathrm{H}_{2} \mathrm{O}+\mathrm{M} \rightarrow \mathrm{M}(\cdot \mathrm{OH})_{\mathrm{ads}}+\mathrm{H}^{+}+\mathrm{e}^{-}$

These electrogenerated hydroxyl radicals are involved in the mineralization of organic pollutants $R$ (present in an aqueous solution) (Eq. 4)

$$
\begin{gathered}
\mathrm{R}_{(\mathrm{aq})}+x \mathrm{M}\left({ }^{\circ} \mathrm{OH}\right)_{\text {ads }} \rightarrow \\
+y \mathrm{M}+\text { Mineralization products } \\
+y \mathrm{H}^{+}+y \mathrm{e}^{-}
\end{gathered}
$$

where $x$ and $y$ are the stoichiometric coefficients.

This reaction (Eq. 4) is in competition with the side reaction of the anodic discharge of these radicals to dioxygen (Eq. 5).

$\mathrm{M}(\cdot \mathrm{OH})_{\mathrm{ads}} \rightarrow \mathrm{M}+\frac{1}{2} \mathrm{O}_{2}+\mathrm{H}^{+}+\mathrm{e}^{-}$

\section{Influence of anode material on the reactivity of electrolytic hydroxyl radicals}

The reaction of organics with electrogenerated electrolytic hydroxyl radicals (Eq. 4) is in competition with the side reaction of the anodic discharge of these radicals to oxygen (Eq. 5). The activity (rate of reaction 4 and 5) of these electrolytic hydroxyl radicals are strongly linked to their interaction with the electrode surface M. As a general rule, the weaker the interaction, the lower is the electrochemical activity (reaction 5 is slow) toward oxygen evolution (high $\mathrm{O}_{2}$ overvoltage anodes) and the higher is the chemical reactivity toward organics oxidation. Based on this approach, we can classify different anode materials according to their oxidation power in acid media; this is shown in Table 1. This table shows that the oxidation potential of the anode (which corresponds to the onset potential of oxygen evolution) is directly related to the overpotential for oxygen evolution and to the adsorption enthalpy of hydroxyl radicals on the anode surface i.e. for a given anode material the higher the $\mathrm{O}_{2}$ overvoltage the higher its oxidation power.

A low oxidation power anode is characterized by a strong electrode-hydroxyl radical interaction resulting in a high electrochemical activity for the oxygen evolution reaction (low overvoltage anode) and to a low chemical reactivity for organic oxidation (low current efficiency for organics oxidation). A typical low oxidation power anode is the $\mathrm{IrO}_{2}$ based electrode [25]. It has been demonstrated, using differential electrochemical mass spectrometry (DEMS) [26], that the interaction between $\mathrm{IrO}_{2}$ and hydroxyl radical at this electrode is so strong that a higher oxidation state oxide $\mathrm{IrO}_{3}$ can be formed. This higher oxide can act as mediator for both organics oxidation and oxygen evolution. 
Table 1 Oxidation power of the anode material used in the electrochemical mineralization (EM) process in acid media

\begin{tabular}{|c|c|c|c|c}
\hline Electrode & $\begin{array}{c}\text { Oxidation } \\
\text { potential } \\
/ \mathbf{V}\end{array}$ & $\begin{array}{c}\text { Overpotential } \\
\text { of } \mathbf{O}_{2} \\
\text { evolution } / \mathbf{V}\end{array}$ & $\begin{array}{c}\text { Adsorption } \\
\text { enthalpy of M- } \\
\text { OH }\end{array}$ & $\begin{array}{c}\text { Oxidation } \\
\text { power of } \\
\text { the anode }\end{array}$ \\
\hline $\begin{array}{c}\mathrm{RuO}_{2}-\mathrm{TiO}_{2} \\
\left(\mathrm{DSA}-\mathrm{Cl}_{2}\right)\end{array}$ & $1.4-1.7$ & 0.18 & $\begin{array}{c}\text { Chemisorption } \\
\text { of OH radical }\end{array}$ & \\
\hline $\begin{array}{c}\mathrm{IrO}_{2}-\mathrm{Ta}_{2} \mathrm{O}_{5} \\
\left(\mathrm{DSA}-\mathrm{O}_{2}\right)\end{array}$ & $1.5-1.8$ & 0.25 & & \\
\hline $\mathrm{Ti} / \mathrm{Pt}$ & $1.7-1.9$ & 0.3 & & \\
\hline $\mathrm{Ti} / \mathrm{PbO}_{2}$ & $1.8-2.0$ & 0.5 & & \\
\hline $\mathrm{Ti} / \mathrm{SnO}_{2}-\mathrm{Sb}_{2} \mathrm{O}_{5}$ & $1.9-2.2$ & 0.7 & & \\
\hline $\mathrm{p}-\mathrm{Si} / \mathrm{BDD}$ & $2.2-2.6$ & 1.3 & $\begin{array}{l}\text { Physisorption } \\
\text { of OH radical }\end{array}$ & \\
\hline
\end{tabular}

In contrast to this low oxidation power anode, the high oxidation power anode is characterized by a week electrodehydroxyl radical interaction resulting in a low electrochemical activity for the oxygen evolution reaction (high overvoltage anode) and to a high chemical reactivity for organics oxidation (high current efficiency for organic oxidation).

The boron-doped diamond based anode (BDD) is a typical high oxidation power anode [27]. By means of spintrapping, the formation of hydroxyl radicals on BDD has been demonstrated [28]. The ESR (Electron Spin Resonance) spectrum (Fig. 1) recorded during electrolysis of DMPO (5.5 dimethyl-1-pyrroline-N-oxide) solution on BDD confirms the formation of $\mathrm{OH}$ during anodic polarization of diamond electrodes. It has been reported, that the BDD-hydroxyl radical interaction is so weak (no free $\mathrm{p}$ or $\mathrm{d}$ orbitals on BDD) that the $\mathrm{OH}$ can even be considered as quasi free. These quasi free hydroxyl radicals are very reactive and can result in the mineralization of the organic compounds according to Eq. 4. Furthermore, BDD anodes have a high overpotential for the oxygen evolution reaction compared to platinum (Fig. 2) [29]. This high overpotential for oxygen evolution at BDD electrodes is certainly related to the weak BDD-hydroxyl radical interaction, what results in the formation of $\mathrm{H}_{2} \mathrm{O}_{2}$ near to the electrode surface (Eq. 6), which is further oxidized at the BDD anode (Eq. 7):

$$
\begin{aligned}
& 2 \mathrm{OH} \rightarrow \mathrm{H}_{2} \mathrm{O}_{2} \\
& \mathrm{H}_{2} \mathrm{O}_{2} \rightarrow 2 \mathrm{H}^{+}+2 \mathrm{e}^{-}+\mathrm{O}_{2}
\end{aligned}
$$

In fact $\mathrm{H}_{2} \mathrm{O}_{2}$ has been detected during electrolysis in $\mathrm{HClO}_{4}$ using BDD anodes as shown in Fig. 3 [30].

\section{Determination of the current efficiency of the electrochemical mineralization}

For the determination of the current efficiency of organic mineralization we consider two parallel reactions:

(a) The main reaction of oxygen transfer from water toward the organic compound:

$\mathrm{R}+x \mathrm{H}_{2} \mathrm{O} \rightarrow$ Mineralization products $+y \mathrm{H}^{+}+y \mathrm{e}^{-}$

(b) The side reaction of oxygen evolution:

$2 \mathrm{H}_{2} \mathrm{O} \rightarrow \mathrm{O}_{2}+4 \mathrm{H}^{+}+4 \mathrm{e}^{-}$

Two techniques have been proposed for the estimation of the instantaneous current efficiency (ICE) during electrolysis: the chemical oxygen demand (COD) and the oxygen flow rate (OFR) techniques.

\subsection{Determination of ICE by the chemical oxygen demand technique}

In this technique, the COD of the electrolyte is measured at regular intervals $(\Delta t)$ during constant current (galvanostatic) electrolysis and the instantaneous current efficiency $\left(\mathrm{ICE}_{\mathrm{COD}}\right)$ is calculated using the relation:
Fig. 1 ESR of DMPO adduct obtained after electrolysis of $8.8 \mathrm{mM}$ DMPO solution in $1 \mathrm{M}$ $\mathrm{HClO}_{4}$ for $2 \mathrm{~h}$ on BDD electrode at $0.1 \mathrm{~mA} \mathrm{~cm}^{-2}$

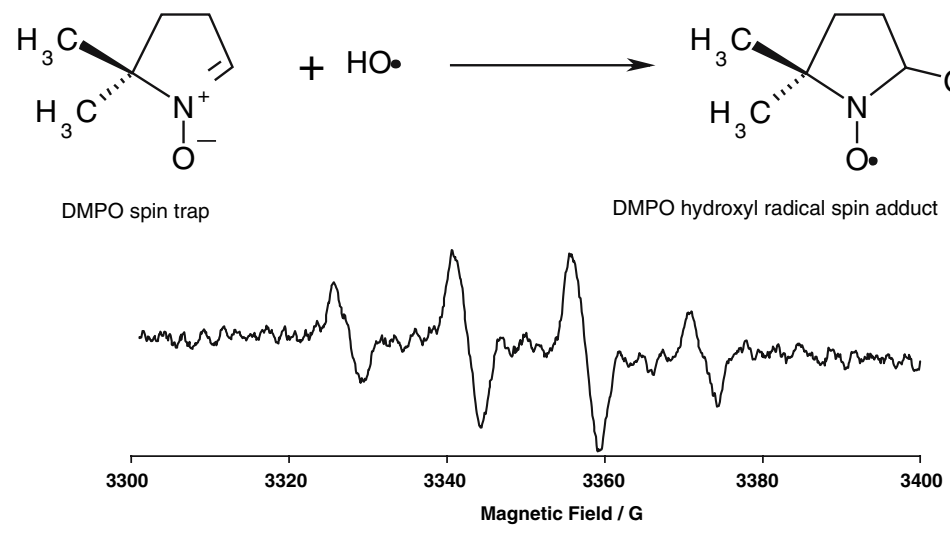




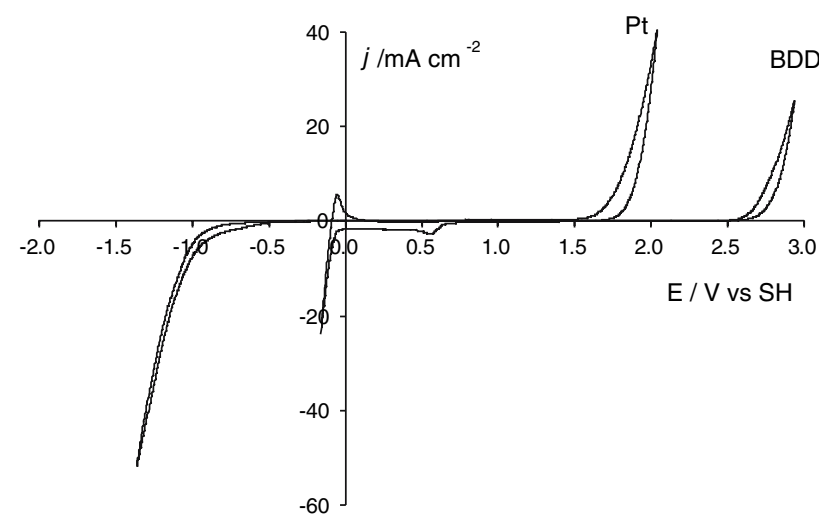

Fig. 2 Cyclic voltammograms of BDD and platinum electrodes; scan rate $50 \mathrm{mVs}^{-1} T=25^{\circ} \mathrm{C}$; Electrolyte: $1 \mathrm{M} \mathrm{HClO}_{4}$

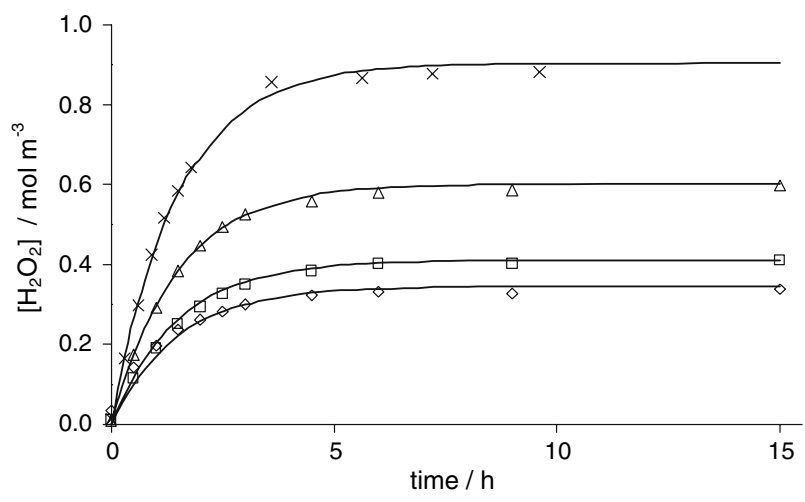

Fig. 3 Production of $\mathrm{H}_{2} \mathrm{O}_{2}$ at different current densities; $(\diamond) 230 \mathrm{~A}$ $\mathrm{cm}^{-2}$, ( $\square$ ) $470 \mathrm{~A} \mathrm{~cm}^{-2},(\Delta) 950 \mathrm{~A} \mathrm{~cm}^{-2}$, (x) $1600 \mathrm{~A} \mathrm{~cm}^{-2}$ during electrolysis of $1 \mathrm{M} \mathrm{HClO}_{4}$ on $\mathrm{BDD}$ electrode

$\mathrm{ICE}_{\mathrm{COD}}=\frac{\mathrm{FV}}{8 \mathrm{I}} \frac{\left[(\mathrm{COD})_{t}-(\mathrm{COD})_{t+\Delta t}\right]}{\Delta t}$

where $(\mathrm{COD})_{t}$ and $(\mathrm{COD})_{t+\Delta t}$ are the chemical oxygen demand $\left(\mathrm{g} \mathrm{O}_{2} \mathrm{~m}^{-3}\right)$ at time $t$ and $t+\Delta t(\mathrm{~s})$ respectively, $\mathrm{I}$ is the applied current (A), $\mathrm{F}$ is the Faraday constant $\left(\mathrm{C} \mathrm{mol}^{-1}\right)$ and $\mathrm{V}$ is the volume of the electrolyte $\left(\mathrm{m}^{3}\right)$.

\subsection{Determination of ICE by the oxygen flow rate technique}

In the OFR technique the oxygen low rate is measured continuously in the anodic compartment during constant current (galvanostatic) electrolysis in a two compartment electrochemical cell. The instantaneous current efficiency $\left(\mathrm{ICE}_{\mathrm{OFR}}\right)$ is then calculated using the relation:

$\mathrm{ICE}_{\mathrm{OFR}}=\frac{\dot{V}_{\mathrm{o}}-\left(\dot{V}_{t}\right)_{\mathrm{org}}}{\dot{V}_{\mathrm{o}}}$

where $\dot{V}_{\mathrm{o}}\left(\mathrm{m}^{-3} \mathrm{~s}^{-1}\right)$ is the theoretical oxygen flow rate calculated from Faraday's law (or measured in a blank experiment in the absence of organic compounds) and $\left(\dot{V}_{t}\right)_{\text {org }}\left(\mathrm{m}^{-3} \mathrm{~s}^{-1}\right)$ is the oxygen flow rate obtained during electrochemical treatment of the wastewater.

Both the COD and OFR techniques have their limitations as given below:

- If volatile organic compounds (VOC) are present in the waste water only the OFR technique will give reliable results.

- If for example $\mathrm{Cl}_{2}(\mathrm{~g})$ is evolved during the treatment (due to the oxidation of $\mathrm{Cl}^{-}$present in the wastewater) only the COD technique will give reliable results.

- If insoluble organic products are formed during the treatment (for example polymeric material) only the OFR technique will give reliable results.

Furthermore, simultaneous application of both the COD and OFR techniques during the electrochemical process will allow better control of the side reactions involved in the electrochemical treatment.

\section{Kinetic model of organics mineralization on BDD anode}

In this section a kinetic model of electrochemical mineralization of organics (RH) on BDD anodes under the electrolysis regime is presented. In this regime, as reported in the previous section, electrogenerated hydroxyl radicals (Eq. 12) are the intermediates for both the main reaction of organics oxidation (Eq. 13) and the side reaction of oxygen evolution (Eq. 14).

$$
\begin{gathered}
\mathrm{BDD}+\mathrm{H}_{2} \mathrm{O} \rightarrow \mathrm{BDD}(\cdot \mathrm{OH})+\mathrm{H}^{+}+\mathrm{e}^{-} \\
\begin{aligned}
x(\cdot \mathrm{OH}) \mathrm{BDD}+\mathrm{R} \rightarrow & x \mathrm{BDD}+\text { Mineralization products } \\
& +y \mathrm{H}^{+}+y \mathrm{e}^{-}
\end{aligned}
\end{gathered}
$$$$
\mathrm{BDD}(\cdot \mathrm{OH}) \rightarrow \mathrm{BDD}+\frac{1}{2} \mathrm{O}_{2}+\mathrm{H}^{+}+\mathrm{e}^{-}
$$

For this simplified reaction scheme (Eqs. 12-14) a kinetic model is proposed based on the following suppositions: (i) adsorption of the organic compounds at the electrode surface is negligible; (ii) all organics have the same diffusion coefficient D; (iii) the global rate of the electrochemical mineralization of organics is a fast reaction and it is controlled by mass transport of organics to the anode surface. The consequence of this last assumption is that the rate of the mineralization reaction is independent of the chemical nature of the organic compound present in the electrolyte. Under these conditions, the limiting current density for the electrochemical mineralization of an organic compound (or a 
mixture of organics) under given hydrodynamic conditions can be written as (Eq. 15):

$i_{\mathrm{lim}}=n F k_{\mathrm{m}} C_{\mathrm{org}}$

where $i_{\text {lim }}$ is the limiting current density for organics mineralization $\left(\mathrm{A} \mathrm{m}^{-2}\right), n$ is the number of electrons involved in organics mineralization reaction, $F$ is the Faraday constant $\left(\mathrm{C} \mathrm{mol}^{-1}\right), k_{\mathrm{m}}$ is the mass transport coefficient $\left(\mathrm{m} \mathrm{s}^{-1}\right)$ and $C_{\mathrm{org}}$ is the concentration of organics in solution $\left(\mathrm{mol} \mathrm{m}^{-3}\right)$. For the electrochemical mineralization of a generic organic compound, it is possible to calculate the number of exchanged electrons, from the following electrochemical reaction:

$$
\begin{aligned}
\mathrm{C}_{x} \mathrm{H}_{y} \mathrm{O}_{z}+(2 x-z) \mathrm{H}_{2} \mathrm{O} \rightarrow & x \mathrm{CO}_{2}+(4 x+y-2 z) \mathrm{H}^{+} \\
& +(4 x+y-2 z) \mathrm{e}^{-}
\end{aligned}
$$

Replacing the value of $n=(4 x+y-2 z)$ in Eq. 15 we obtain:

$i_{\lim }=(4 x+y-2 z) F k_{\mathrm{m}} C_{\mathrm{org}}$

From the equation of the chemical mineralization of the organic compound (Eq. 18),

$\mathrm{C}_{x} \mathrm{H}_{y} \mathrm{O}_{z}+\left(\frac{4 x+y-2 z}{4}\right) \mathrm{O}_{2} \rightarrow x \mathrm{CO}_{2}+\frac{y}{2} \mathrm{H}_{2} \mathrm{O}$

it is possible to obtain the relation between the organics concentration $\left(C_{\text {org }}\right.$ in mol $\left.\mathrm{C}_{x} \mathrm{H}_{y} \mathrm{O}_{z} \mathrm{~m}^{-3}\right)$ and the chemical oxygen demand (COD in $\mathrm{mol} \mathrm{O}_{2} \mathrm{~m}^{-3}$ ):

$C_{\text {org }}=\frac{4}{(4 x+y-2 z)} \mathrm{COD}$

From Eqs. 17 and 19 and at given time $t$ during electrolysis, we can relate the limiting current density of the electrochemical mineralization of organics with the chemical oxygen demand of the electrolyte (Eq. 20):

$i_{\text {lim }}(t)=4 F k_{\mathrm{m}} \mathrm{COD}(t)$

At the beginning of electrolysis, at time $t=0$, the initial limiting current density $\left(i_{\mathrm{lim}}^{0}\right)$ is given by:

$i_{\text {lim }}^{0}=4 F k_{\mathrm{m}} \mathrm{COD}^{0}$

where $\mathrm{COD}^{0}$ is the initial chemical oxygen demand.

We define a characteristic parameter $\alpha$ of the electrolysis process (Eq. 22):

$\alpha=i / i_{\mathrm{lim}}^{0}$
Working under galvanostatic conditions $\alpha$ is constant, and it is possible to identify two different operating regimes: at $\alpha<1$ the electrolysis is controlled by the applied current, while at $\alpha>1$ it is controlled by the mass transport control.

(a) Electrolysis under current limited control $(\alpha<1)$.

In this operating regime $\left(i<i_{\text {lim }}\right)$, the current efficiency is $100 \%$ and the rate of COD removal $\left(\mathrm{mol} \mathrm{O}_{2} \mathrm{~m}^{-2} \mathrm{~s}^{-1}\right)$ is constant and can be written as Eq. 23:

$r=\alpha \frac{i_{\text {lim }}^{0}}{4 F}$

Using relation (21), the rate of COD removal (Eq. 23) can be given by:

$r=\alpha k_{\mathrm{m}} \mathrm{COD}^{0}$

It is necessary to consider the mass-balances over the electrochemical cell and the reservoir to describe the temporal evolution of $\mathrm{COD}$ in the batch recirculation reactor system given in Fig. 4. Considering that the volume of the electrochemical reactor $V_{E}\left(\mathrm{~m}^{3}\right)$ is much smaller than the reservoir volume $V_{R}\left(\mathrm{~m}^{3}\right)$, we can obtain from the mass-balance on COD for the electrochemical cell the following relation:

$Q \mathrm{COD}_{\text {out }}=Q \mathrm{COD}_{\text {in }}-\alpha k_{\mathrm{m}} A \mathrm{COD}^{0}$

where $Q$ is the flow-rate $\left(\mathrm{m}^{3} \mathrm{~s}^{-1}\right)$ through the electrochemical cell, $\mathrm{COD}_{\text {in }}$ and $\mathrm{COD}_{\text {out }}$ are the chemical oxygen demands $\left(\mathrm{mol} \mathrm{O}_{2} \mathrm{~m}^{-3}\right)$ at the inlet and at the outlet of the electrochemical cell, respectively, and $A$ is the anode

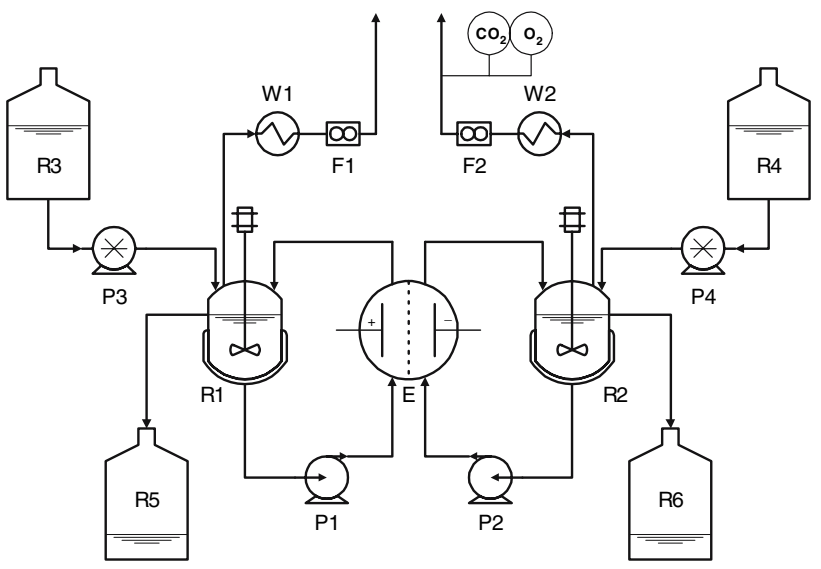

Fig. 4 Scheme of the two-compartments electrochemical flow cell; R-reservoirs; P-pumps; E-electrochemical cell with membrane; $\mathrm{W}$-heat exchangers, F-gas flow controllers; Electrode surface $64 \mathrm{~cm}^{2}$; Volume of reservoir R1 and R2 $250 \mathrm{~mL}$ 
area $\left(\mathrm{m}^{2}\right)$. For the well-mixed reservoir (Fig. 4) the mass balance on COD can be expressed as:

$Q\left(\mathrm{COD}_{\text {out }}-\mathrm{COD}_{\text {in }}\right)=\mathrm{V}_{\mathrm{R}} \frac{d \mathrm{COD}_{\text {in }}}{d t}$

Combining Eqs. 25-26 and replacing $\mathrm{COD}_{\text {in }}$ by the temporal evolution of chemical oxygen demand COD, we obtain:

$\frac{d \mathrm{COD}}{d t}=-\alpha \frac{\operatorname{COD}^{0} A k_{\mathrm{m}}}{V_{\mathrm{R}}}$

Integrating this equation subject to the initial condition $\mathrm{COD}=\mathrm{COD}^{0}$ at $t=0$ gives the evolution of $\operatorname{COD}(t)$ with time in this operating regime $\left(i<i_{\mathrm{lim}}\right)$ :

$\operatorname{COD}(t)=\operatorname{COD}^{0}\left(1-\alpha \frac{A k_{\mathrm{m}}}{V_{R}} t\right)$

This behavior persists until a critical time $\left(t_{\mathrm{cr}}\right)$, at which the applied current density is equal to the limiting current density, which corresponds to:

$\mathrm{COD}_{\mathrm{cr}}=\alpha \mathrm{COD}^{0}$

Substituting Eq. 29 in Eq. 28 it is possible to calculate the critical time:

$t_{\mathrm{cr}}=\frac{1-\alpha}{\alpha} \frac{V_{\mathrm{R}}}{A k_{\mathrm{m}}}$

or in term of critical specific charge $\left(\mathrm{Ah} \mathrm{m}^{-3}\right)$ :

$Q_{\mathrm{cr}}=i_{\lim }^{0} \frac{(1-\alpha)}{k_{\mathrm{m}} 3600}=\frac{4 F \mathrm{COD}^{0}(1-\alpha)}{3600}$

(b) Electrolysis under mass transport control $(\alpha>1)$.

When the applied current exceeds the limiting one (i > $i_{\text {lim }}$ ), secondary reactions (such as oxygen evolution) commence resulting in a decrease of the instantaneous current efficiency (ICE). In this case, the COD mass balances on the anodic compartment of the electrochemical cell $E$ and the reservoir $R 2$ (Fig. 4 ) can be expressed as:

$\frac{d \mathrm{COD}}{d t}=-\frac{A k_{\mathrm{m}} \mathrm{COD}}{V_{R}}$

Integration of this equation from $t=t_{\mathrm{cr}}$ to $t$, and $\mathrm{COD}=\alpha \cdot \mathrm{COD}^{0}$ to $\operatorname{COD}(t)$ leads to:
$\operatorname{COD}(t)=\alpha \operatorname{COD} \exp \left(-\frac{A k_{m}}{V_{R}} t+\frac{1-\alpha}{\alpha}\right)$

The instantaneous current efficiency (ICE) can be defined as:

$\mathrm{ICE}=\frac{i_{\lim }}{i}=\frac{\operatorname{COD}(t)}{\alpha \operatorname{COD}^{0}}$

And from Eqs. 33 and 34, ICE is now given by:

$\mathrm{ICE}=\exp \left(-\frac{A k_{\mathrm{m}}}{V_{\mathrm{R}}} t+\frac{1-\alpha}{\alpha}\right)$

A graphical representation of the proposed kinetic model is given in Fig. 5. In order to verify the validity of this model, the anodic oxidation of various aromatic compounds in acidic solution has been performed varying organics concentration and current density.

\subsection{Influence of the nature of organic pollutants}

Figure 6 shows both the experimental and predicted values (continuous line) of both ICE and COD evolution with the specific electrical charge passed during the anodic oxidation of different classes of organic compounds (acetic acid, isopropanol, phenol, 4-chlorophenol, 2-naphtol) [29]. This figure demonstrates that the electrochemical treatment is independent on the chemical nature of the organic compound. Furthermore, there is excellent agreement between the experimental data and predicted values from proposed model.

\subsection{Influence of organic concentration}

Figure 7 presents both ICE and COD evolution with the specific electrical charge passed during the galvanostatic oxidation (238 A m $\mathrm{A} \mathrm{m}^{-2}$ ) of 2-naphtol $(2-9 \mathrm{mM})$ in $1 \mathrm{M}$ $\mathrm{H}_{2} \mathrm{SO}_{4}$ [31]. As predicted from the model, the critical specific charge $Q_{\mathrm{cr}}$ (Eq. 31) increases with increase in initial organic concentration (reported as initial $\mathrm{COD}^{0}$ ). Again, there is excellent agreement between the experimental and predicted values.

\subsection{Influence of applied current density}

The influence of current density on both ICE and COD evolution with the specific electrical charge passed during the galvanostatic oxidation of a $5 \mathrm{mM}$ 2-naphtol in $1 \mathrm{M}$ $\mathrm{H}_{2} \mathrm{SO}_{4}$ at different current densities (119-476 $\mathrm{A} \mathrm{m}^{-2}$ ) is shown in Fig. 8 [31]. As previously, excellent agreement between the experimental and predicted values is observed. 
Fig. 5 Evolution of (a) COD and (b) ICE in function of time (or specific charge); (A) represents the charge transport control; (B) represents the mass transport control
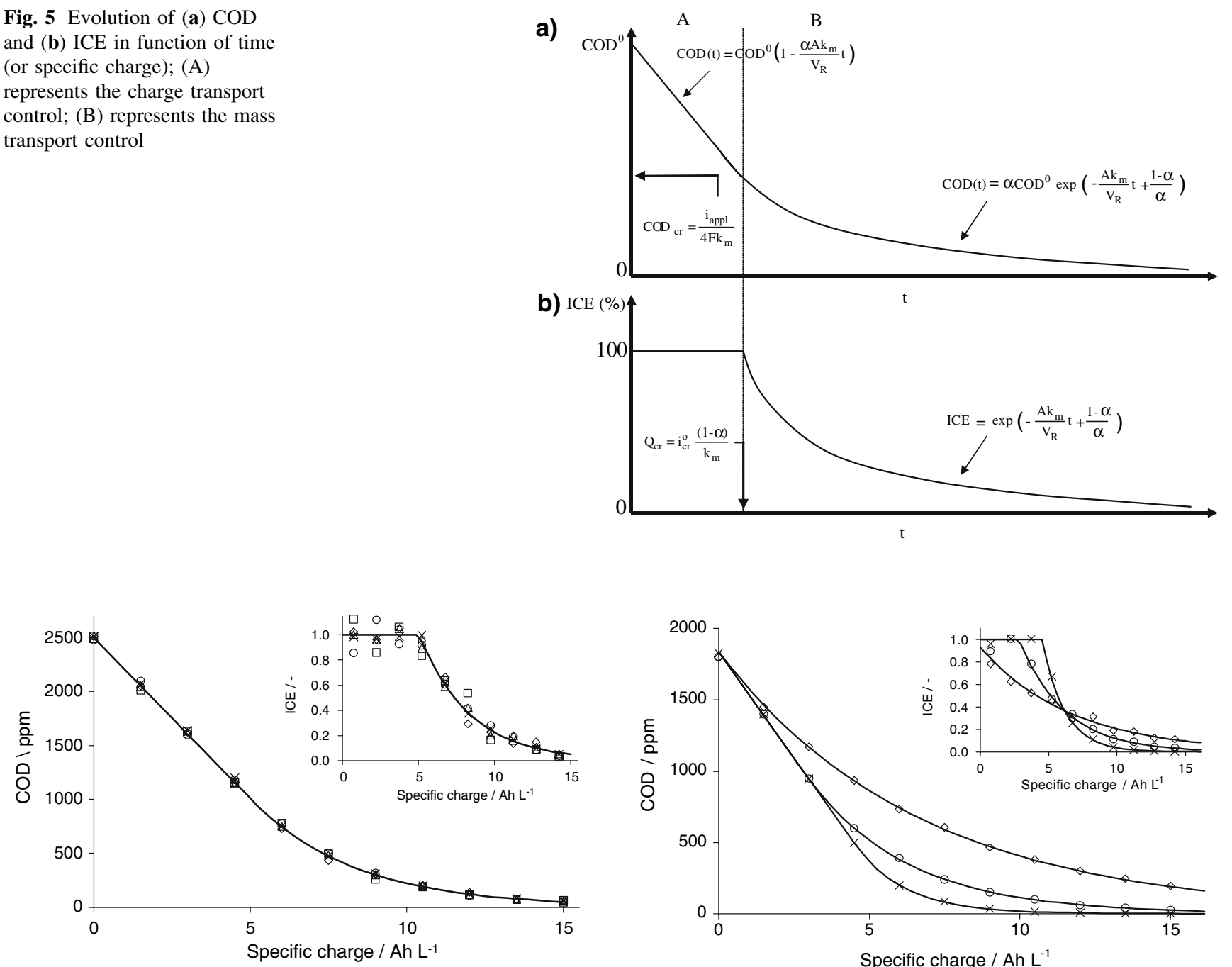

Fig. 6 Evolution of COD and ICE (inset) in function of specific charge for different organic compounds: (x) acetic acid, ( $\square$ ) isopropanol, (o) phenol, ( $\Delta$ ) 4-chlorophenol, $(\diamond)$ 2-naphtol; $i=$ $238 \mathrm{~A} \mathrm{~m}^{-2} ; T=25^{\circ} \mathrm{C}$; Electrolyte: $1 \mathrm{M} \mathrm{H}_{2} \mathrm{SO}_{4}$; The solid line represents model prediction

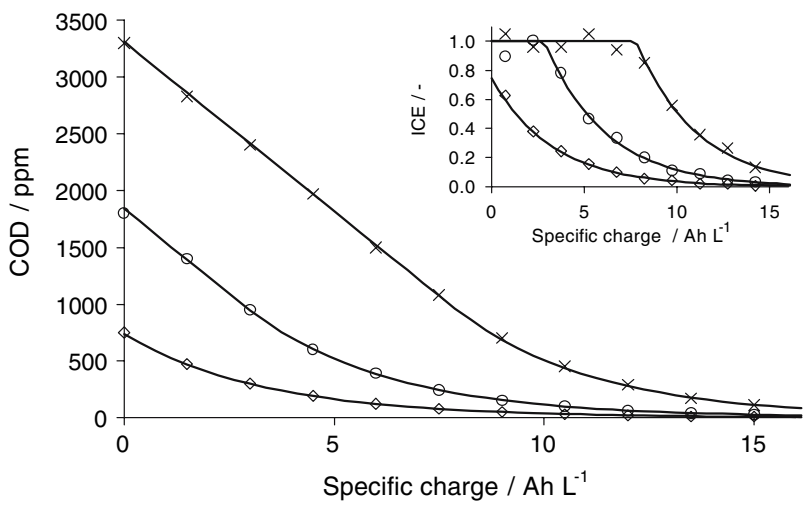

Fig. 7 Influence of the initial 2-naphtol concentration, (x) $9 \mathrm{mM}$, (o) $5 \mathrm{mM},(\diamond) 2 \mathrm{mM}$ on the evolution of COD and ICE (inset) during electrolysis on BDD; $i=238 \mathrm{~A} \mathrm{~m}^{-2} ; T=25^{\circ} \mathrm{C}$; Electrolyte: $1 \mathrm{M}$ $\mathrm{H}_{2} \mathrm{SO}_{4}$; The solid line represents model prediction

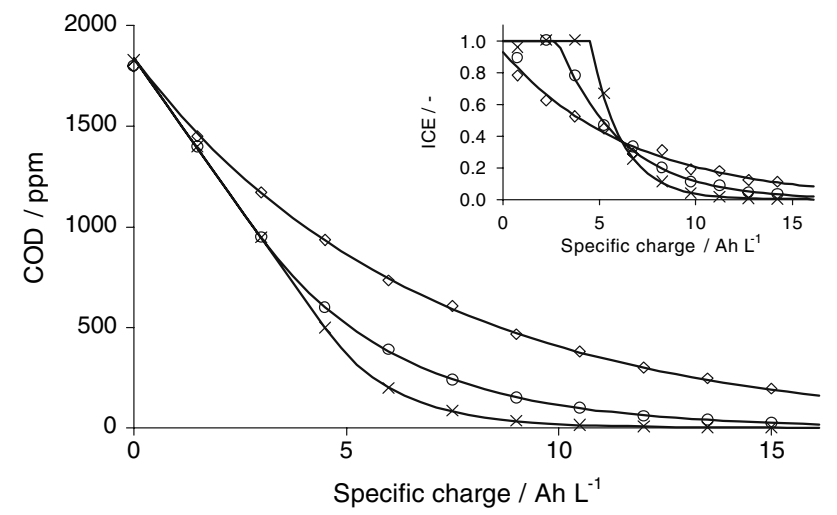

Fig. 8 Influence of the applied current density, (x) $119 \mathrm{~A} \mathrm{~m}^{-2}$, (o) $238 \mathrm{~A} \mathrm{~m}^{-2},(\diamond) 476 \mathrm{~A} \mathrm{~m}^{-2}$ on the evolution of COD and ICE (inset) during electrolysis of $5 \mathrm{mM}$ 2-naphtol in $1 \mathrm{M} \mathrm{H}_{2} \mathrm{SO}_{4}$ on BDD; $T=$ $25{ }^{\circ} \mathrm{C}$; The solid line represents model prediction

\section{Intermediates formed during the electrochemical mineralization process}

It has been found that the amount and nature of intermediates formed during the electrochemical mineralization of organics on BDD anodes depends strongly on the working regime. In fact, electrolysis under conditions of current limited control results usually in the formation of a significant number of intermediates in contrast to electrolysis under mass transport control, where practically no intermediates are formed and $\mathrm{CO}_{2}$ is the only final product. Figure 9 shows a typical example of phenol oxidation under conditions of current limited control (formation of aromatic intermediates) and mass transport regime (no intermediates, only $\mathrm{CO}_{2}$ ) [13]. 


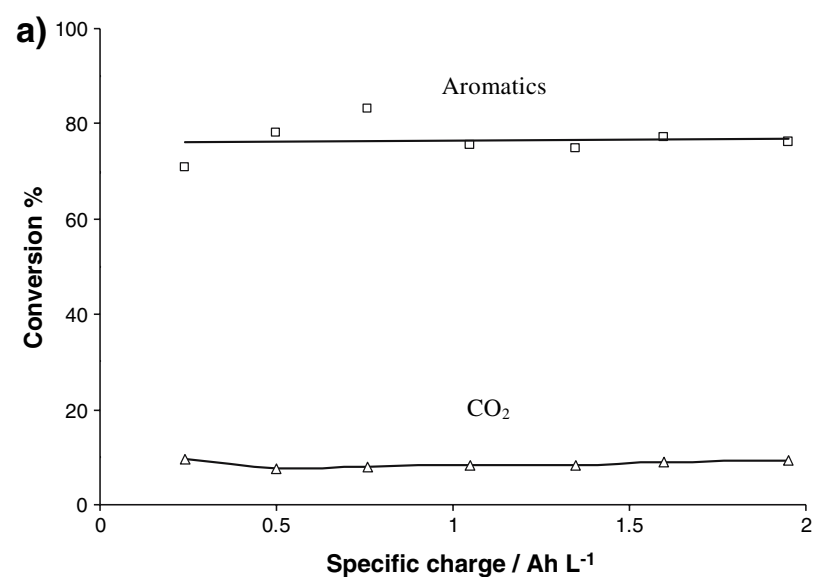

$\mathrm{EOI}=\frac{\int_{0}^{\tau} \mathrm{ICE} d t}{\tau}$ with $0 \leq \mathrm{EOI} \leq 1$

where ICE is the instantaneous current efficiency (-) and $\tau$ is the duration of the electrochemical treatment (s). Using the numerical values, Eq. 36 can be written as:

$E_{\mathrm{sp}}=107.2 \frac{V_{\mathrm{c}}}{\mathrm{EOI}}$ with $0 \leq \mathrm{EOI} \leq 1$

The cell potential can be related to the current density by the relation (Eq. 39):

$V_{\mathrm{c}}=V_{0}+\rho d i$

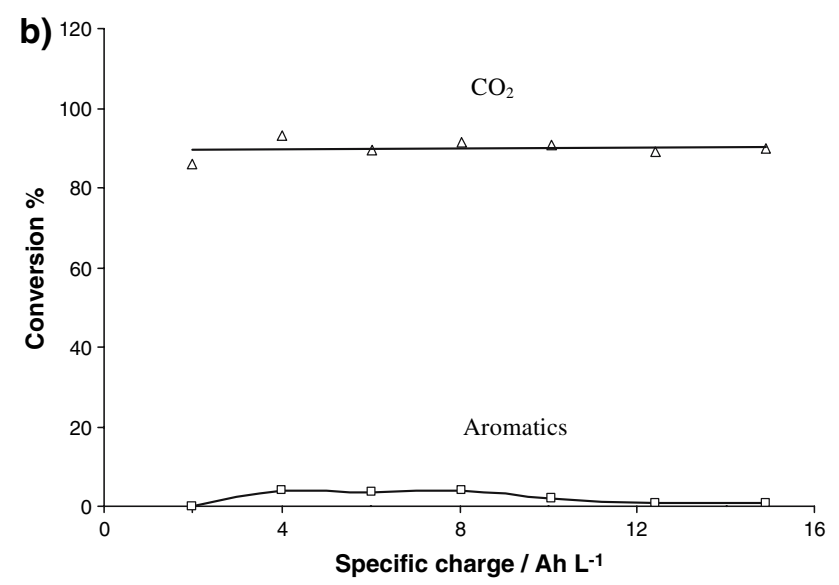

Fig. 9 Trend of the percentage of phenol converted to $\mathrm{CO}_{2}(\Delta)$ and to aromatic compounds $(\square)$ during phenol electrolysis in $1 \mathrm{M} \mathrm{HClO}_{4}$ on BDD under (a) current limited control, initial phenol concentration: $20 \mathrm{mM}$, current density $5 \mathrm{~mA} \mathrm{~cm}^{-2}$; (b) mass transport control, initial phenol concentration: $5 \mathrm{mM}$, current density $60 \mathrm{~mA} \mathrm{~cm}{ }^{-2}$

\section{Electrical energy consumption in the electrochemical mineralization process}

In contrast to the chemical oxidation process in which strong oxidants (usually in the presence of catalysts) are used in order to achieve efficient treatment, the electrochemical process consumes mainly electrical energy. The specific energy consumption for the electrochemical treatment of a given wastewater can be estimated from the relation (36) [31]:

$E_{\mathrm{sp}}=\frac{4 F V_{\mathrm{c}}}{3600 \mathrm{EOI}}$ with $0 \leq \mathrm{EOI} \leq 1$

where $E_{\mathrm{sp}}$ is the specific energy consumption $(\mathrm{kWh} / \mathrm{kmol}$ COD), $F$ is Faraday's constant $\left(\mathrm{C} \mathrm{mol}{ }^{-1}\right.$, $) V_{\mathrm{c}}$ is the cell potential $(\mathrm{V})$ and EOI is the electrochemical oxidation index (which represents the average current efficiency for organics oxidation) given by Eq. 37 :

where $V_{0}$ is the constant depending on the nature of the electrolyte $(\mathrm{V}), \rho$ is the resistivity of the electrolyte $(\Omega \mathrm{m})$, $d$ is the inter-electrode distance (m) and $i$ is the current density $\left(\mathrm{A} \mathrm{m}^{-2}\right)$. Combining Eqs. 38 and 39 gives:

$E_{\mathrm{sp}}=107.2 \frac{\left(V_{\mathrm{o}}+\rho d i\right)}{\mathrm{EOI}}$ with $0 \leq \mathrm{EOI} \leq 1$

This relation shows that the specific energy consumption decreases with increasing average current efficiency, reaching a minimum value at $\mathrm{EOI}=1$.

\section{Optimization of the electrochemical mineralization using BDD anodes}

As shown in the previous section, the specific energy consumption for the electrochemical mineralization of organics decreases strongly with increasing average current efficiency (EOI) and reaches a minimum value at $\mathrm{EOI}=1$. In order to work under these favorable conditions (at which EOI $=1$ ), electrolysis has to be carried out under programmed current, in which the current density during electrolysis is adjusted to the limiting value. The following steps are proposed for optimal treatment of a wastewater using BDD anodes:

(a) Measure the initial chemical oxygen demand $\left(\mathrm{COD}^{0}\right)$ of the wastewater.

(b) Estimate the mass transfer coefficient $\left(k_{\mathrm{m}}\right)$ of the electrolytic cell under fixed hydrodynamic conditions (stirring rate). This can be achieved using a given concentration of $\mathrm{Fe}(\mathrm{CN})_{6}^{4-}(50 \mathrm{mM})$ in a supporting electrolyte $(1 \mathrm{M} \mathrm{NaCl})$ and measuring the limiting current $\left(I_{\mathrm{lim}}\right)$ for the anodic oxidation of $\mathrm{Fe}(\mathrm{CN})_{6}^{4-}$. The mass transfer coefficient $\left(k_{\mathrm{m}}\right)$ can then be calculated using the relation: 
$k_{m}=\frac{I_{\mathrm{lim}}}{F A\left[\mathrm{Fe}(\mathrm{CN})_{6}^{4-}\right]}$

where $k_{m}$ is the mass transfer coefficient $\left(\mathrm{m} \mathrm{s}^{-1}\right), I_{m}$ is the limiting current $(\mathrm{A}),\left[\mathrm{Fe}(\mathrm{CN})_{6}^{4-}\right]$ is the concentration of $\left[\mathrm{Fe}(\mathrm{CN})_{6}^{4-}\right]\left(\mathrm{mol} \mathrm{m}^{-3}\right), F$ is the Faraday constant $\left(\mathrm{C} \mathrm{mol}^{-1}\right)$ and $A$ is the anode surface area $\left(\mathrm{m}^{2}\right)$.

(c) Estimate the initial limiting current density $\left(i_{\text {lim }}\right)$ for the electrochemical mineralization using Eq. 21.

(d) Calculate the time constant of the electrolytic cell $\left(\tau_{c}\right)$ using the relation:

$\tau_{\mathrm{c}}=\frac{V_{R}}{A k_{\mathrm{m}}}$

where $\tau_{\mathrm{c}}$ is the electrolytic cell time constant (s), $V_{R}$ is the volume of the reservoir $R 2$ in Fig. $4\left(\mathrm{~m}^{3}\right)$.

(e) Using Eqs. 21, 33, 42 and considering $\alpha=1$ (initial applied current density $=$ calculated initial limiting current density) we obtain the theoretical temporal evolution of the limiting current during electrolysis (Eq. 42).

$i_{\mathrm{lim}}=i_{\mathrm{lim}}^{0} \exp \left(-\frac{t}{\tau_{\mathrm{c}}}\right)$

(f) Start electrolysis by application of a current density corresponding to the limiting value (calculated as in point $\mathrm{c}$ ).

(g) Adjust the current density during electrolysis to the time dependent limiting value according to Eq. 43.

(h) From Eqs. 21 and 43, calculate the electrolysis time $(\tau)$ in order to achieve the target final COD value $\left(\mathrm{COD}_{\text {final }}\right)$ using the relation:

$\tau=-\tau_{\mathrm{c}} \log \frac{\mathrm{COD}_{\text {final }}}{\mathrm{COD}^{0}}$

\section{Conclusions}

This paper summarizes research carried out on electrochemical oxidation of organic pollutants for wastewater treatment over the past 10 years. The nature of the anode material strongly influences the reactivity towards organic oxidation. The key factor in enhanced oxidation is the interaction of electrogenerated hydroxyl radicals with the electrode surface. In general, high oxidation power anodes are characterized by a week electrode-hydroxyl radical interaction resulting in a high current efficiency for organic oxidation and a low electrochemical activity for the oxygen evolution. Based on this, boron-doped diamond can be considered as an ideal anode material for electrochemical mineralization of organic wastes.
The proposed theoretical kinetic model of organic mineralization on boron-doped diamond anodes allows prediction of the evolution of chemical oxygen demand and current efficiency during organic oxidation. The experimental verification of the model at several levels (influence of the nature of the organic pollutants, organic concentration and applied current density) shows excellent agreement with theory in all investigated cases.

\section{References}

1. Comninellis Ch, Plattner E (1988) Chimia 42:250

2. Comninellis Ch, Pulgarin C (1991) J Appl Electrochem 21: 703

3. Seignez C, Pulgarin C, Peringer P, Comninellis Ch, Plattner E (1992) Swiss Chem 14:25

4. Comninellis Ch (1992) Gas, Wasser, Abwasser 72:792

5. Comninellis Ch, Pulgarin C (1993) J Appl Electrochem 23: 108

6. Pulgarin C, Adler N, Peringer P, Comninellis Ch (1994) Water Res 28:887

7. Comninellis Ch (1994) Electrochim Acta 39:1857

8. Comninellis Ch, Nerini A (1995) J Appl Electrochem 25:23

9. Simond O, Schaller V, Comninellis Ch (1997) Electrochim Acta 42:2009

10. Fóti G, Gandini D, Comninellis Ch (1997) Curr Top Electrochem $5: 71$

11. Ouattara L, Chowdhry MM, Comninellis Ch (2004) New Diam Front Carbon Techn 14:239

12. Comninellis Ch, De Battisti A (1996) J Chim Phys 93:673

13. Iniesta J, Michaud P-A, Panizza M, Cerisola G, Aldaz A, Comninellis Ch (2001) Electrochim Acta 46:3573

14. Chen X, Gao F, Chen G, Yue PL (2003) Environ Sci Technol 37:5021

15. Ouattara L, Duo I, Diaco T, Ivandini A, Honda K, Rao T, Fujishima A, Comninellis, Ch (2003) New Diam Front Carbon Techn 13:97

16. Zanta CLPS, Michaud P-A, Comninellis Ch, De Andrade AR, Boodts JFC (2003) J Appl Electrochem 33:1211

17. Polcaro AM, Mascia M, Palmas S, Vacca A (2004) Electrochim Acta 49:649

18. Brillas E, Boye B, Sires I, Garrido JA, Rodriguez RM, Arias C, Cabot P-L, Comninellis Ch (2004) Electrochim Acta 49:4487

19. Haenni W, Rychen P, Fryda M, Comninellis Ch (2004) Semicond Semimet 77:149

20. Martinez-Huitle CA, Quiroz MA, Comninellis Ch, Ferro S, De Battisti A (2004) Electrochim Acta 50:949

21. Polcaro AM, Vacca A, Mascia M, Palmas S (2005) Electrochim Acta 50:1841

22. Chen X, Gao F, Chen G (2005) J Appl Electrochem 35:185

23. Boye B, Brillas E, Marselli B, Michaud P-A, Comninellis Ch, Farnia G, Sandonà G (2006) Electrochim Acta 51:2872

24. Panizza M, Cerisola G (2005) Electrochim Acta 51:191

25. Fóti G, Gandini D, Comninellis Ch, Perret A, Haenni W (1999) Electrochem Solid-State Lett 2:228

26. Fierro S, Nagel T, Baltruschat H, Comninellis C (2007) Electrochem Commun 9:1969

27. Fóti G, Comninellis C (2004) In: Conway BE, White RE, Vayenas CG (eds) Modern aspects of electrochemistry, vol 37. Kluwer Academic/Plenum Publishers, New York, p 87 
28. Marselli B, Garcia-Gomez J, Michaud P-A, Rodrigo MA, Comninellis C (2003) J Electrochem Soc 150:D79

29. Michaud PA (2002) Comportement anodique du diamond synthetique dope au bore, $\mathrm{PhD}$ thesis, Ecole Polytechnique Fédérale de Lausanne, Switzerland
30. Michaud P-A, Panizza M, Ouattara L, Diaco T, Foti G, Comninellis C (2003) J Appl Electrochem 33:151

31. Panizza M, Michaud P-A, Cerisola G, Comninellis C (2001) J Electroanal Chem 507:206 